\title{
New landlords: problems and solutions: Part 2
}

Alan Dowling

\author{
Senior Lecturer in Law, Queen's University Belfast
}

\begin{abstract}
$\mathrm{T}$ The first part of the examination of the law concerning the rights and liabilities of successors in title of a landlord ${ }^{1}$ dealt with the period up to the passing of the Landlord and Tenant Law Amendment Act (Ireland) 1860, invariably, despite the stricture noted by Palles $\mathrm{CB},{ }^{2}$ called Deasy's Act. In this part, the law contained in that and subsequent measures is considered. The matters identified in the first part of the article as the matters of concern to someone who acquires property which is subject to a tenancy remain the same: the new landlord will be concerned to ensure that the rent is paid, and that the obligations undertaken by the tenant are performed and observed. Those, therefore, are the focus of the examination presently being undertaken. A new landlord will want, however, not only to know the benefits which will accrue to him or her: but also be concerned about the obligations which will be passed on when the takeover is completed. The extent to which the obligations of the original landlord will be binding on any successor must therefore also be considered in the discussion.
\end{abstract}

\section{Legislation}

One of the peculiarities of the law of landlord and tenant in Ireland is that in some cases the law governing the position of the parties may be found in two different enactments whose provisions do not correspond. The period under discussion in this part of the examination of the law which governs the position of a new landlord begins with the enactment of Deasy's Act. Two decades later, the provisions of the Conveyancing and Law of Property Act 1881 were enacted and made applicable to Ireland. It is the incongruity of some of the provisions in these enactments that poses the difficulties. It is clear that the provisions of Deasy's Act and those of the Conveyancing Act overlap in some instances, and that in such cases a new landlord wishing to recover rent or to enforce covenants in a lease against the lessee could look to either for assistance. The same is the case if it is the lessee who wishes to enforce covenants undertaken by the lessor against a new landlord. If, for example, a fee simple owner of land makes a lease by deed for twenty-five years, reserving a rent, and with a covenant by the lessee to keep the property in repair, someone who purchases the owner's estate will be able to recover the rent and enforce the covenant by reason of the provisions of either statute. Equally, if the lease contains an obligation by

1 A Dowling, "New landlords: problems and solutions: Part 1" (2008) 59(3) NILQ 249-89.

2 Irish Land Commission v Holmes (1898) 32 ILTR 85 at 86. 
the lessor to repair the property, the lessee will be able to enforce the obligation against the new landlord by relying either on Deasy's Act or on the Conveyancing Act. In a number of cases, however, the two sets of provisions do not correspond exactly, and in such cases the plaintiff may be able to recover by reason of one statute only. The discussion which follows, therefore, proceeds by considering the provisions of each enactment which are relevant to matters of concern to a new landlord, such as recovery of rent or enforcement of covenants. Before that, however, it is possible to identify some situations where one or other (but not both) of the enactments in question will be applicable to the situation. In order to identify these situations, it is convenient at this stage to set out the provisions of s. 10 of the 1881 Act, though further comment on the provisions of the section will be necessary later.

The section provides as follows:

Rent reserved by a lease, and the benefit of every covenant or provision therein contained, having reference to the subject-matter thereof, and on the lessee's part to be observed or performed, and every condition of re-entry and other condition therein contained, shall be annexed and incident to and shall go with the reversionary estate in the land, or in any part thereof, immediately expectant on the term granted by the lease, notwithstanding severance of that reversionary estate, and shall be capable of being recovered, received, enforced, and taken advantage of by the person from time to time entitled, subject to the term, to the income of the whole, or any part, as the case may require, of the land leased.

It is apparent that the section deals with a number of matters: rent and its recovery; the benefit of covenants entered into by a lessee, and their enforcement; and conditions in a lease. These are considered below, but for the moment it is other aspects of the section that are of concern, namely: the applicability of the section only where there is a lease; the annexation of the various matters referred to in the section to the reversionary estate; and the ability to enforce payment of rent and performance of the lessee's covenants being based on entitlement to the income of the land leased. These requirements do not exist in the sections of Deasy's Act which are relevant to the situation where a new landlord wishes to recover rent and enforce covenants against a lessee, or where a lessee wishes to enforce covenants against the new landlord. From the provisions in s. 10, it is therefore possible to identify a number of situations involving successors in title to the original parties to a tenancy where only the provisions of Deasy's Act can regulate the rights and obligations of those concerned, or alternatively only the provisions of the Conveyancing Act will govern the situation.

\section{TENANCIES CREATED ORALLY}

Both before and since Deasy's Act, it has been possible for a tenancy to be created orally in some instances. ${ }^{3}$ In the case of such a tenancy, a new landlord seeking to rely on statutory provisions to enable rent to be recovered or covenants to be enforced against the tenant will be able to rely only on the provisions of Deasy's Act. Section 45, which provides for recovery of rent by action, and ss 12 and 13, which regulate the enforcement of covenants, apply respectively to rent reserved by and to agreements contained in "the lease or other contract of tenancy". While "lease" is defined in s. 1 to mean an instrument in writing, "other contract of tenancy" immediately following must refer to tenancies created otherwise than in writing, and so include tenancies created orally and tenancies arising by implication from the acts of the parties, as where a tenant holds over after the expiry of a lease and rent is paid and received. In contrast, the provisions of s. 10 of the Conveyancing Act apply only where there is an instrument in writing. The section refers to rent reserved

3 See Deasy's Act, s. 4. 
by a lease, and to the benefit of covenants "therein contained". Although "lease" is not defined in the 1881 Act, the decisions on the section show that while the term is not restricted to an instrument under seal, ${ }^{4}$ a tenancy created otherwise than by instrument in writing does not come within the provisions of the section. ${ }^{5}$

\section{TENANCIES WITH NO REVERSION}

One of the alterations to the law of landlord and tenant in Ireland effected by Deasy's Act was to enable the relation of landlord and tenant to be created although the landlord did not retain a reversion in the land that was the subject of the tenancy. ${ }^{6}$ Consequently, it became possible for the relation to exist in cases where it would not exist at common law. Perhaps the most obvious result of this provision of the section is the existence in Ireland of fee farm grants creating the relation of landlord and tenant between grantor and grantee. ${ }^{7}$ For this, and any other case where no reversion is retained, the provisions of Deasy's Act will be relevant for a new landlord: those of the Conveyancing Act will not, since they refer to rent and covenants being annexed to the landlord's reversionary estate.

\section{TENANCIES RESERVING NO RENT}

Conversely, one case which falls within the Conveyancing Act, but may not come within the provisions of Deasy's Act, is that of a tenancy in which no rent is reserved. Strictly, this misstates the problem, since the question is whether an arrangement which would otherwise be a tenancy is prevented in Ireland from being a tenancy if no rent is reserved. At common law there is no difficulty, rent not being an essential element for the relation of landlord and tenant to exist. ${ }^{8}$ Accordingly, if a lease is created in which there is no reservation of rent, the case will still fall within the provisions of the Conveyancing Act. The difficulty in Ireland is that it may not come within the provisions of Deasy's Act. The problem arises because of the definition of "lease" in s. 1 of Deasy's Act, and because of s. 3 of the Act. In s. 1, "lease" is defined as an instrument in writing containing a contract of tenancy "in consideration of a rent or return". Section 3 states that the relation of

4 In this regard, the position under the Conveyancing Act is different from that under the Grantees of Reversions Act 1540 and the Statute of Reversions (Ireland) 1634, which applied only where the tenancy had been created by deed. Independently, however, of the Conveyancing Act, the significance of a seal was considered by Denning LJ in Boyer v Warbey [1953] 1 All ER 269 at 274 to have diminished by reason of the Judicature Act 1873 (cf. Judicature Act (Ireland) 1877): "I know that before the Supreme Court of Judicature Act, 1873, it was said that the doctrine of covenants running with the land only applied to covenants under seal and not agreements under hand . . . but since the fusion of law and equity the position is different. The distinction between agreements under hand and covenants under seal has been largely obliterated. There is no valid reason nowadays why the doctrine of covenants running with the land - or with the reversion - should not apply equally to agreements under hand as to covenants under seal, and I think we should so hold, not only in the case of agreements for more than three years which need the interposition of equity to perfect them, but in the case of agreements for three years or less which do not." The reference to agreements for three years is to the requirements in the Law of Property Act as to formalities in England and Wales.

5 See Rickett v Green [1910] 1 KB 253 (landlord's successor successful in proceedings for possession where letting contained in instrument in writing not under seal, the court considering the case within the doctrine of Walsh v Lonsdale (1882) LR 21 Ch D 9 and the parties as in the position they would have been in had a lease under seal existed); Cole v Kelly [1920] 2 KB 106 (correspondence recording parties' agreement for tenancy following the expiration of lease held sufficient for the purposes of s. 10); Rye v Purcell [1926] 1 KB 446 (letter containing terms of tenancy sufficient though signed only by landlord). Contrast Blane v Francis [1917] 1 KB 252 (landlord's successor unable to enforce repairing obligation where tenancy had arisen by implication from tenant's holding over after expiry of lease).

6 Deasy's Act, s. 3.

7 Such grants can no longer be created: see Property (NI) Order 1997, Art. 28(1).

8 Ashburn Anstalt v Arnold [1998] 2 All ER 147. 
landlord and tenant exists in all cases where there is an agreement by one party to hold land from or under another "in consideration of any rent". The absence of an obligation to pay rent therefore prevents an instrument being a lease, and accordingly, s. 12 can only apply to an arrangement where no rent is payable if the arrangement can come within it as being a "contract of tenancy". The problem in doing so is s. 3, which seems to make rent a necessity. ${ }^{9}$

The problems posed by Deasy's Act for arrangements under which no rent is payable may be of interest to academics, but are of little practical significance for present purposes, for two reasons. First, practitioners have long been aware of the problem of rent-free arrangements and have overcome it by providing for payment of a nominal rent, in order to avoid the doubt raised by Deasy's Act and so ensure that the relation of landlord and tenant will be created. Secondly, and more fundamentally, since the premise upon which the present discussion is based is the attraction of tenanted land as an investment for a new landlord, an arrangement under which no rent is payable by the occupier is hardly likely to be one which will make the purchase of the landlord's interest attractive.

\section{LANDLORD'S TITLE TO SUE}

A question still to be considered in comparing the provisions of the two enactments concerns the title of the new landlord to sue. While in many cases a successor to the original landlord may come within the terms of both statutes, the different terminology used in the statutes means that in some cases a new landlord may come within one of the statutes but not the other.

So far as Deasy's Act is concerned, the relevant sections base the ability to sue simply on being the landlord at the relevant time. Section 45 of Deasy's Act provides that "every person entitled to any rent" may bring an action to recover the rent. Likewise, s. 12 of the Act provides that "every landlord" has the same action and remedy for breach of the agreements by the tenant as the original landlord had. Other sections dealing with remedies for the landlord refer simply to "the landlord" or to "any landlord". 10 "Landlord" is defined in s. 1 as including the person for the time being entitled in possession to the estate or interest of the original landlord, whether the interest has been acquired by assignment, devise, bequest or act and operation of law. ${ }^{11}$ The term clearly covers the ordinary case of someone who acquires the estate formerly held by the original landlord. Though authority is lacking, the expression is unlikely to include some individuals who do fall within s. 10 of the Conveyancing Act.

Under s. 10 of the Conveyancing Act, the plaintiff's ability to sue is based on the plaintiff being "the person from time to time entitled, subject to the term, to the income of the whole, or any part, as the case may require, of the land leased". The expression clearly covers someone who acquires the estate of the original landlord, even where the title to the land is registered and the transfer to the new landlord has not yet been registered. ${ }^{12}$ Beyond that, however, the section has been held to mean that a mortgagor of the land can bring an action, so long as the mortgagee has neither taken possession nor given notice of the

9 Such was the view of Kenny J (dissenting) in Irish Shell \& BP Ltd v Costello Ltd [1981] ILRM 66.

10 See ss 52 (ejectment for non-payment of rent) and 51 (distraint) respectively.

11 So, in Liddy v Kennedy (1871) LR 5 HL 134, the original landlord and his brother together constituted "the landlord" following the execution by the original landlord of a deed whereby the original landlord covenanted to stand seised of the land to the use of himself and his brother as tenants in common, thereby overcoming the argument by the tenant that there had been a severance of the reversion: see below, p. 365 .

12 Scribes West Ltd v Relsa Anstalt and Others (No. 3) [2004] EWCA Civ 1744. 
intention to do so. ${ }^{13}$ Formerly, the mortgagee as assignee of the reversion would have been the proper plaintiff in an action to recover rent or to enforce the covenants in the lease. Such would seem to remain the position under Deasy's Act. ${ }^{14}$ Mortgagors apart, the question is whether the terms of s. 10 would enable others who would not come within Deasy's Act to bring an action for the rent or to enforce covenants by a lessee. ${ }^{15}$

\section{Recovery of rent}

The various courses of action open to a landlord to secure payment for the land let by him or her were considered in the first part of this article. To recover rent, the landlord might bring an action of debt, or of covenant if there was a covenant by the tenant to pay the rent. In cases where there was a promise, but the promise was not under seal, an action of assumpsit might be available instead. Alternatively, the landlord might bring an action for reasonable satisfaction for the tenant's use and occupation of the land. Independently altogether of litigation, the landlord had the ability to distrain for rent due, or might be able to terminate the tenancy if there was a right to re-enter in the event of non-payment of rent. Both Deasy's Act and the Conveyancing Act contain provisions concerning the recovery of payment for the tenant's enjoyment of the land.

\section{DEASY'S ACT}

Deasy's Act preserved the various options available to a landlord seeking to recover rent or a reasonable satisfaction for the use and occupation of the landlord's land. The Act made little alteration to the law as to distraint for rent. ${ }^{16}$ Ejectment for non-payment of rent was dealt with to a greater extent, s. 52 providing a means by which a landlord could bring proceedings where a year's rent was in arrear under one of the various forms of tenancy mentioned in the section, and the sections following making provision for various matters concerning the action. Landlords wishing simply to obtain judgment for money due to them could look to ss 45 and 46. Both sections remain in force. By the former, every person entitled to any rent in arrear under any lease or other contract of tenancy may bring an action to recover such arrear from the tenant of the land at the time the arrear accrued. By the latter, every person entitled to any lands who suffers the lands to be held or occupied under an agreement not specifying the amount of rent may recover by action a reasonable satisfaction for the use and occupation of the land. In each case, the opening words of the section ("Every person entitled ...") are wide enough to enable successors in title to the original landlord to bring the action in question. Section 45 makes clear that those entitled to bring an action for rent include persons acting in representative capacities, referring to

13 Turner $\mathrm{v}$ Walsh [1909] $2 \mathrm{~KB} 484$.

14 See, however, Judicature (NI) Act 1978, s. 93 (replacing Judicature Act (Ireland) 1877, s. 28(5)), which enables a mortgagor to sue for rent though the reversion is in a mortgagee. For the effect of the 1877 Act, see Patterson v O’Reilly (1882) 10 LR Ir 304. Under the corresponding provision of the Judicature Act 1873 a mortgagor was unable to sue for damages for breach of covenant by a lessee (Turner $\mathrm{v}$ Walsh [1909] 2 KB 484) or to recover possession based on forfeiture, the right to forfeit being in the mortgagee and not having been exercised by the mortgagee (Matthews $\mathrm{v}$ Usher [1900] 2 QB 535).

15 In Shalit v Joseph Nadler Ltd [1933] 2 KB 79, a beneficiary under a trust declared by the landlord was held not to be a person entitled to the rent under the corresponding provisions of the Law of Property Act, and so was unable to distrain for rent, since his entitlement was not to the rent, but to an account from his trustee of the profits received from the land.

16 S. 51 provided that it would not be lawful to distrain for rent accruing due more than a year before. The absence of other provisions dealing with distraint is perhaps the most obvious difference between Deasy's Act and the Bill introduced in 1852 which is the source of the provisions of the Act (see below, p. 356). Cll 68-97 of the earlier Bill made extensive provision for distraint, but only cl. 68 was enacted in Deasy's Act, as s. 51. 
cases where the plaintiff is entitled to the rent in right of his see, dignity, benefice or corporation, or in right of his wife, or as executor or administrator of any party deceased.

\section{CONVEYANCING ACt 1881}

The recovery of rent by a successor in title to the landlord is also provided for under the Conveyancing Act. Section 10 of the Act provides that rent reserved by a lease is annexed and incident to and shall go with the reversionary estate in the land, and is capable of being recovered by the person from time to time entitled, subject to the term, to the income of the whole, or any part of the land leased. Those who later acquire the reversion acquire therefore also the rent reserved by the lease and can enforce payment of the rent. ${ }^{17}$ The position of mortgagors and others who do not have the reversion has already been considered.

\section{APPORTIONMENT}

The position at common law was that rent was not apportionable in respect of the period to which it related, so that the person who was entitled to the landlord's interest on the day rent fell due was entitled also to the whole of the rent then payable, even if it related in part to a period when the landlord's interest was owned by someone else. The position changed by statutes of 1783 and 1834, but these were repealed by Deasy's Act and new provisions put in their place. ${ }^{18}$ One of these provisions, s. 50, remains in force, ${ }^{19}$ and provides that, in cases not falling within s. 34 of the Act, a landlord is entitled to a reasonable proportion of the rent payable under a tenancy where the tenancy determines between gale days otherwise than by an act of the landlord. ${ }^{20}$ Not long after Deasy's Act however, other provisions for apportionment of rent were enacted in the Apportionment Act 1870. Section 2 of the 1870 Act provides that rents are to be considered as accruing from day to day and are apportionable in respect of time accordingly. The effect of the Act where the new landlord was a devisee of the original landlord can be seen in Roseingrave v Burke, ${ }^{21}$ where Chatterton $\mathrm{V}-\mathrm{C}$ held that the Act had made an apportionment necessary as between the new landlord and the original landlord's estate. ${ }^{22}$ Whether the same reasoning would apply in the case of

17 For an argument that the effect of the section was to change the nature of the right to rent from an interest in land to a contractual right see Inland Revenue Commissioners v John Lewis Properties plc [2002] 1 WLR 35. The basis of the argument was that since, by the section, rent is annexed to the reversionary estate and goes with it, a transferee of the reversion will be entitled to the rent despite the prior assignment by the landlord of the right to receive the rent to another party. The argument was rejected by Lightman J. The decision of the Court of Appeal ([2003] Ch 513) does not deal with the point.

18 Deasy's Act, ss 49 and 50.

19 S. 49 was repealed by the Statute Law Revision Act 1893.

20 S. 50 reads: "In every case not coming within the provisions of clause thirty-four, when the tenancy determines otherwise than by the act of the landlord, at any time before the day on which the rent would become payable, the landlord, at the time of such determination (unless it is otherwise agreed), shall be entitled to a reasonable proportion of the rent according to the time that has elapsed from the commencement of the tenancy, or the last gale day, to the day of the determination of such tenancy, including such day."

21 (1873) IR 7 Eq 186. The case was followed in England the following year in Capron v Capron (1874) LR 17 Eq 288. See also Hasluck v Pedley (1874) LR 19 Eq 271; Constable v Constable (1879) 11 Ch D 681; In re Ford [1911] 1 Ch 455.

22 In reaching a decision different from that in Sealy v Stawell (1868) IR 2 Eq 326, decided before the 1870 Act came into force, the Vice-Chancellor explained (at 191): "But the Statute since enacted [the 1870 Act] appears to me to affect the question materially. It makes rents to accrue from day to day, and therefore, for the purposes of apportionment, makes each day's rent of the nature of an accrued and completed gale. It would therefore, in my opinion, in order to pass the portion of a current half-yearly gale, accrued before the testator's death, with the estate in the lands to the devisee, require words as clear as to give him a gale the whole of which had accrued due before the death." 
a gift inter vivos does not seem to have been decided. Where the new landlord is a purchaser, the contract between the parties will determine whether an apportionment is needed. In the ordinary case, a vendor is entitled to the rents and profits up to completion, so that an apportionment will be required where completion takes place between the dates on which rent is payable. ${ }^{23}$ So far as the tenant of the land is concerned, however, the Act adopted the same procedure as had existed under the earlier legislation, namely that the tenant should pay the whole of the rent to the new landlord when it fell due, but the original landlord or the landlord's estate would be entitled to recover from the new landlord the proportionate part attributable to the period before the transfer of the land to the new landlord. ${ }^{24}$

\section{Covenants}

The difficulties at common law for successors in title to a landlord lay not so much in impediments to the recovery of rent, but with the enforcement of covenants, and led in England to the enactment of the Grantees of Reversions Act 1540, and in Ireland to the Statute of Reversions (Ireland) 1634. The Statute of Reversions is one of the measures repealed by Deasy's Act. ${ }^{25}$ In place of the provisions of the Statute of Reversions, Deasy's Act contained provisions which continue to govern the rights and obligations of successors in title to the original parties to a tenancy today. Unfortunately, they are not the only provisions: ss 10 and 11 of the Conveyancing and Law of Property Act 1881 are also of relevance in determining the ability of a successor to a landlord to enforce the obligations of the tenant, and the liability of new landlord.

\section{DEASY'S ACT}

\section{Sections 12 and 13}

Sections 12 and 13 of Deasy's Act provide for the enforcement by a new landlord of the obligations of a tenant, and the liability of a new landlord to a tenant on covenants undertaken by the original landlord. Simplifying matters by omitting consideration of the tenant's successors, the sections provide that an assignee of the landlord has the same action

23 See Coal Commission v Earl Fitzwilliam's Royalty Co [1942] Ch 365. Contrast In re Dawson's Estate (1888) 21 LR Ir 441 where Monroe $\mathrm{J}$ held a purchaser entitled to the full rent payable after completion of the contract, referring to the practice of the court being based on the assumption that the Apportionment Act did not apply. The explanation for the decision in In re Dawson's Estate lies in Waldon v Condon (1854) $3 \mathrm{Ir}$ Ch R 431, in which Cusack Smith MR explained that in cases of sales in the Incumbered Estates Court the purchaser was required to pay the purchase money into court shortly after the contract was made, and so should be entitled to the full rent payable by tenants of the land.

24 Apportionment Act, s. 4 (proviso). If the new landlord's title is itself a leasehold title, the 1870 Act will also operate on the rent which is payable by the new landlord. If the transfer takes place between days appointed for payment of rent, the new landlord as assignee of the lease will be liable to the superior landlord only for a proportionate part of the rent payable to the superior landlord: see Glass v Patterson [1902] 2 IR 660. Note, however, the comments of Kenny J, dissenting, at 664: "It is a somewhat singular circumstance to find this point only now for the first time raised in a definite shape in this country . . I can account for the absence of authoritative decision only on the assumption that no one thought of questioning what was generally supposed to be the liability of the tenant's assignee, who became such assignee in the interval between two gales, for the full gale of rent that became due and payable while the estate was vested in him. If the Act does apply in the manner and to the extent contended for by the defendant, I can only say I am confident that not only has property been uniformly dealt with on a wholly different basis during these thirty-two years as between three sets of parties, namely - (1) landlords and their tenant's assignees; (2) successive owners of the tenant's interests; and (3) successive owners of the landlord's estate - but that the result of holding that there is an apportionment in such cases as the present will be to create mischiefs and inconveniences, instead of in the words of the statute - removing them." See also Swansea Bank Ltd v Thomas (1879) 4 Ex D 94; Parry v Robinson-Wyllie Ltd (1987) 54 P \& CR 187. 
and remedy against the tenant as the original landlord had, for breach by the tenant of the agreements contained in the tenancy. Correspondingly, the liability of a new landlord appears intended to be the same as that of the original landlord, the sections providing that a tenant has the same action and remedy against an assignee of the landlord as existed against the original landlord, for breach of the agreements on the part of the landlord contained in the tenancy.

Looking at the sections in more detail, s. 12 of Deasy's Act provides as follows:

Every landlord of any lands holden under any lease or other contract of tenancy shall have the same action and remedy against the tenant, and the assignee of his estate or interest, or their respective heirs, executors, or administrators, in respect of the agreements contained or implied in such lease or contract, as the original landlord might have had against the original tenant, or his heir or personal representative respectively; and the heir or personal representative of such landlord on whom his estate or interest under any such lease or contact shall devolve or should have devolved shall have the like action and remedy against the tenant, and the assignee of his estate or interest, and their respective heirs or personal representatives, for any damage done to the said estate or interest of such landlord by reason of the breach of any agreement contained or implied in the lease or other contract of tenancy in the lifetime of the landlord, as such landlord himself might have had.

Section 13 provides:

Every tenant of any lands shall have the same action and remedy against the landlord and the assignee of his estate or interest, or their respective heirs, executors, or administrators, in respect of the agreements contained or implied in the lease or other contract concerning the lands, as the original tenant might have had against the original landlord, or his heir or personal representative respectively; and the heir or personal representative of such tenant on whom his estate or interest shall devolve, or should have devolved, shall have the like action and remedy against the landlord, and the assignee of his estate or interest, and their respective heirs and personal representatives, for any damage done to the said estate or interest of such tenant by reason of the breach of any agreement contained or implied in the lease or other contract of tenancy in the lifetime of the tenant, as such tenant might have had.

The provisions of s. 12 have been justifiably described as convoluted. ${ }^{26}$ The same is true for those of s. 13. Before considering how the sections altered the law which existed before 1861 in relation to successors in title to the landlord, a word about the origin of the provisions may be appropriate, as the history of the provisions throws some light on one question which has given rise to discussion subsequently, namely the reference in s. 13, but not in s. 12, to agreements "concerning the lands".

\section{Parliamentary history}

The origins of Deasy's Act have been charted elsewhere. ${ }^{27}$ Briefly, the measure began life as one of four Bills introduced by Joseph Napier, Attorney General for Ireland, on behalf of the Government in 1852, in an effort to solve what is known as the Irish land problem. Opposition to some of the measures, along with changes in government, contributed to the failure to enact the measures. In the ensuing years attempts were made to have the measures passed. Eventually, in 1860, the Government saw through the passage of what was

26 J C W Wylie, Landlord and Tenant Law 2nd edn (Horsham: Tottel, 1998), para 21.22.

27 A Dowling, "The genesis of Deasy's Act” (1989) 40 NILQ 53 
essentially the least controversial of the Bills of 1852, as Deasy's Act. So far as ss 12 and 13 of Deasy's Act are concerned, the origins of the provisions can be traced to Bills introduced in 1854. A comparison of Bills published in July $1853^{28}$ and June $1854^{29}$ shows the evolution of the original text proposed by Napier into what became ss 12 and 13 of Deasy's Act. In that evolution, not only did the provisions become more complicated, they acquired the words "concerning the lands" which had been absent from the clauses of the earlier Bill. ${ }^{30}$ The wording appears, however, in both clauses of the 1854 Bill. ${ }^{31}$ The similarity between the clauses of the 1854 Bill and the provisions of ss 12 and 13 of Deasy's Act is obvious at a glance. Not so obvious is the omission from s. 12 of the words in question. It seems reasonable to suppose that ss 12 and 13 were intended to be mirror images of each other: that at least appears to have been the intention of the corresponding provisions in the earlier Bills. Unfortunately, when later the Bill ${ }^{32}$ which became Deasy's Act was prepared, the words "concerning the lands" were omitted from what became s. 12, while remaining in what became s. $13 .{ }^{33}$ Given the consistency of the provisions in the earlier Bills, either in the exclusion of the expression from each of the respective clauses, or in its

28 (1852-3) British Parliamentary Papers (House of Commons) iv. 167 (Bill No. 796).

29 (1854) British Parliamentary Papers (House of Commons) iii. 381 (Bill No. 130).

$30 \mathrm{Cl} .15$ of the 1853 Bill provided: "Every Tenant, whether by original Contract, lawful Assignment, or by Operation of Law, of any Lands holden under any Lease, or of any Part thereof, and his Executors and Administrators, shall have the same Action and Remedy against the Landlord, and the Assignee of his Estate and Interest, or of any Part thereof, in respect of all the Agreements contained in the Lease, as the original Tenant might have had against the original Landlord." Cl. 16 read: "Every Landlord, whether by original Contract or lawful Assignment, Devise, Bequest, or Act and Operation of Law, of any Lands holden under any Lease, or of any Part thereof, and his Heirs, Executors, and Administrators, shall have the same Action and Remedy against the Tenant and the Assignee of his Estate or Interest, or any Part thereof, in respect of the Agreements contained in the Lease, as the original Landlord might have had against the original Tenant." Cl. 16 differs slightly from that in Napier's original Bill, which did not contain the words "Devise, Bequest, or Act and Operation of Law”: see (1852-3) British Parliamentary Papers (House of Commons) iv. 45 (Bill No. 18).

$31 \mathrm{Cl} .13$ of the 1854 Bill provided: "Every Landlord, whether by original Contract, lawful Assignment, Devise, Bequest, or Act and Operation of Law, of any Lands holden under any Lease or other Contract of Tenancy shall have the same Action and Remedy against the Tenant, and the Assignee of his Estate or Interest, or their respective Heirs, Executors or Administrators, in respect of the Agreements contained or implied in the Lease or other Contract concerning the Lands, as the original Landlord might have had against the original Tenant, or his Heir or personal Representative respectively, and the Heir or personal Representative of such Landlord on whom his Estate or Interest under any such Lease or Contract shall devolve or should have devolved shall have the like Action and Remedy against the Tenant, and the Assignee of his Estate or Interest, and their respective Heirs or personal Representatives, for any damage done to the said Estate or Interest of such Landlord by reason of the Breach of any Agreement contained or implied in the Lease or other Contract of Tenancy in the Lifetime of the Landlord, as such Landlord himself might have had." Cl. 14 read: "Every Tenant, whether by original Contract, lawful Assignment, Devise, Bequest or Act and Operation of Law, of any Lands holden under any Lease or other Contract of Tenancy shall have the same Action and Remedy against the Landlord and the Assignee of his Estate or Interest, or their respective Heirs, Executors, or Administrators, in respect of the Agreements contained or implied in the Lease or other Contract concerning the Lands, as the original Tenant might have had against the original Landlord, or his Heir, or personal Representative respectively; and the Heir or personal Representative of such Tenant on whom his Estate or Interest shall devolve or should have devolved, shall have the like Action and Remedy against the Landlord, and the Assignee of his Estate or Interest, and their respective Heirs, and personal Representatives, for any Damage done to the said Estate or Interest of such Tenant by reason of the breach of any Agreement contained or implied in the Lease or other Contract of Tenancy in the Lifetime of the Tenant, as such Tenant might have had."

32 (1860) British Parliamentary Papers (House of Commons) iv. 21 (Bill No. 92).

33 It should be pointed out, however, that the expression is not the only one which appears in s. 12 of the Act but is missing, or partially missing, from s. 13. Section 12 refers to lands "holden under any lease or other contract of tenancy", and later to the interest of a landlord "under any such lease or contract", whereas s. 13 refers in the corresponding locations of the section simply to a tenant of lands and the interest of such tenant. 
inclusion in each case, the omission of the expression from s. 12 and its appearance in s. 13 is unfortunate. Whether the omission of the expression from s. 13 was deliberate or accidental is not clear from the parliamentary debates or elsewhere, and the choices of explanation seem therefore to be either that the sections should be seen as mirror images notwithstanding the appearance in the one but not the other of the expression, or that the difference signifies an unexplained intention that the sections operate differently. Consistency and the absence of any expressed reason why the sections should operate differently are arguments for the former.

\section{CONVEYANCING ACt 1881}

A number of provisions in the 1881 Act need to be mentioned in connection with the ability of a successor in title to enforce covenants in the lease.

\section{Sections 6 and 63}

Sections 6 and 63 of the 1881 Act are some of the "word saving" provisions of the Act, designed to avoid the need for conveyances to set out in detail all the matters intended to pass under the deed in question, and which led to the Act acquiring the soubriquet the Drudgery of Conveyancers Relief Act. ${ }^{34}$ By s. 6(1) it is provided that a conveyance is deemed to include and to convey (inter alia) all rights appertaining to the land. ${ }^{35}$ In Kumar v Dunning, ${ }^{36}$ it was argued that the equivalent provision in the Law of Property Act $1925^{37}$ meant that a successor in title to a landlord acquired the benefit of a surety covenant made with the landlord. The action was between an original tenant and the surety, who had entered into the covenant with the landlord in consideration of the landlord giving consent to an assignment of the lease. Some time later the landlord assigned the reversion to a successor, who brought an action against the original tenant when the assignee of the lease failed to pay the rent. The tenant paid the sum due, and now sought to recover from the surety, on the basis that the tenant was entitled to be subrogated to the rights of the new landlord. The success of the action depended on whether the new landlord had acquired the benefit of the surety covenant, the tenant arguing that he had, because of the equivalent provision to s. 6(1) of the Conveyancing Act, there having been no express assignment of the benefit of the covenant. The court disagreed, Browne-Wilkinson V-C holding that even if the benefit of a covenant could be said to come within the expression "rights . . . appertaining to the land", a right under covenant could not appertain to the land unless the benefit was in some way annexed to the land. The court went on, however, for other reasons, to find that the new landlord could have enforced the surety covenant, and so the tenant was entitled to be subrogated to the rights of the new landlord and his action against the surety succeeded. ${ }^{38}$

34 See Re Healing Research Trustee Co Ltd [1992] 2 All ER 481 at 485.

35 S. 6(1) provides: "A conveyance of land shall be deemed to include and shall by virtue of this Act operate to convey, with the land, all buildings, erections, fixtures, commons, hedges, ditches, fences, ways, waters, watercourses, liberties, privileges, easements, rights, and advantages whatsoever, appertaining or reputed to appertain to the land, or any part thereof, or at the time of conveyance demised, occupied, or enjoyed with, or reputed or known as part or parcel of or appurtenant to the land or any part thereof."

36 [1987] 2 All ER 801.

37 S. 62(1).

38 See p. 374, below. 
Section 63 is another provision intended to simplify conveyancing, by providing that a conveyance is effectual to pass all the estate of the grantor in the property conveyed. ${ }^{39}$ Speaking of the corresponding provision of the Law of Property Act $1925,{ }^{40}$ Lindsay J explained that:

Its object, like that of section 63 of the 1881 Act, was to avoid the litany of express mentions of ancillaries and sweepings up which, in order to ensure that everything passed that could pass with the conveyance, had become the standard language of conveyancers. ${ }^{41}$

Whether the benefit of a break clause in a lease passed to an assignee of the lease by reason of s. 63 of the Law of Property Act 1925 was the issue in Harbour Estates Ltd v HSBC Bank $p l c,{ }^{42}$ Lindsay $\mathrm{J}$ holding that it did, overcoming the argument that the break clause, by being expressed to be personal to the lessee, could not be relied on by an assignee, by regarding the clause as touching and concerning, or having reference to the subject matter of, the lease, and its benefit accordingly passing as a right "in, to or on the property conveyed", within the meaning of the statutory provision. The reasoning appears equally applicable were the situation was concerned with a new landlord rather than an assignee of a lessee.

While, therefore, s. 63 of the 1881 Act may incidentally enable successors in title to the original parties to a lease to sue on covenants contained in the lease, it is the provisions of ss 10 and 11 of the Act which are primarily intended to achieve that purpose.

\section{Sections 10 and 11}

As with rent, s. 10 annexes to the reversionary estate in land demised by a lease the benefit of the covenants undertaken by the lessee in the lease. Removing references to rent and conditions, the section provides that, for leases made after the end of 1881, the benefit of every covenant or provision in a lease, having reference to the subject matter thereof, and on the lessee's part to be observed and performed, is annexed to and goes with the reversionary estate in the land. The section further provides that the benefit of such covenants can be taken advantage of by the person from time to time entitled, subject to the term, to the income of the land leased.

While s. 10 provides that a new landlord will enjoy the benefit of covenants entered into by the lessee with the lessor, s. 11 provides that, in the case of leases made after 1881, the new landlord will be subject to the burden of covenants made by the lessor with the lessee, and will be liable to the lessee for breach of such covenants. The section provides as follows:

The obligation of a covenant entered into by a lessor with reference to the subject-matter of a lease shall, if and as far as the lessor has power to bind the reversionary estate immediately expectant on the term granted by the lease, be annexed and incident to and shall go with that reversionary estate, or the several parts thereof, notwithstanding severance of that reversionary estate, and may be taken advantage of and enforced by the person in whom the term is from time to time vested by conveyance, devolution in law, or otherwise; and, if and as far as the lessor has power to bind the person from time to time entitled to that reversionary estate, the obligation aforesaid may be taken advantage of and enforced against any person so entitled.

39 S. 63(1) reads: "Every conveyance shall, by virtue of this Act, be effectual to pass all the estate, right, title, interest, claim and demand which the conveying parties respectively have in, to or on the property conveyed, or expressed or intended so to be, or which they respectively have power to convey in, to or on the same."

40 S. 63.

41 Harbour Estates Ltd v HSBC Bank plc [2005] Ch 194 at [30].

42 [2005] Ch 194. 


\section{DIFFERENCES}

The situations in which either the provisions of Deasy's Act, or those of the Conveyancing Act, but not both, can apply have already been considered. In cases, however, where the provisions of both enactments apply, a new landlord may prefer to rely on one enactment rather than the other, because of the differences in the relevant provisions.

\section{Collateral covenants}

Under the Grantees of Reversions Act, only covenants which touched and concerned the land were enforceable by and against successors to the original parties to the tenancy. The position under the Conveyancing Act is the same. Although neither s. 10 nor s. 11 of the Conveyancing Act uses the expression, the references to covenants "having reference to the subject matter thereof [i.e. of a lease]" in s. 10 and "having reference to the subject matter of a lease" in s. 11 have been held to mean the position is the same under the 1881 Act as pertained under the Grantees of Reversions Act. ${ }^{43}$ The limitation means, for example, that a new landlord is not bound by an option granted to the lessee to purchase the lessor's estate; ${ }^{44}$ or by a right of pre-emption; 45 or by an obligation to repay money deposited by the lessee as security for the rent; ${ }^{46}$ or by a covenant to pay a sum to the lessee at the end of the tenancy. ${ }^{47}$ On the other hand, it also means that the benefit of certain covenants entered into by the lessee will not be enforceable by a new landlord.

Whether the position is the same under the provisions of Deasy's Act is a question for which no satisfactory answer exists. We have seen already that s. 13 contains the expression "concerning the lands" when referring to agreements which are enforceable against successors of the landlord, and that there is no corresponding expression in s. 12. Leaving aside the question as to why the expression appears in the one section but not in the other, there remains the question whether it was intended to import the same requirement as existed before 1861, namely that only covenants which touch and concern the land are enforceable between successors. The hope expressed in $1944^{48}$ that light would soon be shed on the darkness has yet gone unfulfilled. Lyle $\mathrm{v} S$ mith $^{49}$ remains the one case where any significant discussion of the sections has taken place. ${ }^{50}$ In it, after stating his view that Deasy's Act was intended to get rid of technical rules, Gibson J went on to say that:

The express language of sections 12 and 13 cannot be restricted or altered by forcing on it Spencer's Case applicable to the law of covenants at common law, which was so precious in the eyes of legal schoolmen that they could hardly conceive a statute disregarding it. ${ }^{51}$

43 Davis v Town Properties Investment Corpn Ltd [1903] 1 Ch 797; Hua Chiao Commercial Bank Ltd v Chiaphua Industries Ltd [1987] AC 99; Caerns Motor Services Ltd v Texaco Ltd [1994] 1 WLR 1249.

44 Woodall v Clifton [1905] 2 Ch 257. Insofar, however, as the option creates an equitable interest in the lessee, the option may be enforceable against a new landlord on the basis that the new landlord will be bound by equitable interests in the land unless he or she is a bona fide purchaser for value of a legal estate without notice. The need for registration must also, however, be taken into account: see Webb v Pollmount [1966] Ch 584.

45 Charles Frodham \& Co Ltd v Morris (1972) 229 EG 961.

46 Hua Chiao Commercial Bank Ltd v Chiaphua Industries Ltd [1987] AC 99.

47 Re Hunter's Lease [1942] Ch 124.

48 M G Bready, “Covenants affecting land” (1944) 6 NILQ 48, at 59.

49 [1909] 2 IR 58.

50 Notable for the lack of discussion of the sections are Athol v Great Western Railway Co (1868) IR 3 CL 333, Borrowes v Delaney (1889) 24 LR Ir 503 and Fitzgerald v Sylver (1928) 62 ILTR 51.

51 Lyle v Smith [1909] 2 IR 58 at 76. 
While this might suggest that the provisions of the sections are such that all the obligations which the original parties to a tenancy undertake pass to their successors, Gibson J did allow that some obligations might not burden successors to the party who undertook them, mentioning terms depending on personal considerations and not capable of vicarious performance, and collateral agreements disconnected with the land. ${ }^{52}$ Unfortunately, Gibson J thought it undesirable to attempt an exhaustive definition as to covenants which are within or outside the statute. ${ }^{53}$

The only other case which requires mention for its comment on the question whether ss 12 and 13 are subject to the restrictions which applied in the law before they came into force is Borrowes $\mathrm{v}$ Delaney, ${ }^{54}$ though whether the case lightens the darkness or makes it deeper is another question. The relevant comment is Andrews J's statement that even assuming the covenant in question not to run with the land, the assignee of the lease "was entitled to the right which was incident to the tenancy by virtue of the covenant when he became assignee". 55 Whether, and if so, how, this expression differs from the "touch and concern" formula is not explained.

The result therefore is that a new landlord seeking to enforce a covenant in the lease against the tenant, or a tenant wishing to enforce a covenant against the new landlord, in reliance on the provisions of the Conveyancing Act, will be able to do so only if the covenant is one which would have been described before 1881 as touching and concerning the land, and, since 1881, is, in the phraseology of the Conveyancing Act, one which has reference to the subject matter of the lease. If it is not, there remains hope that the provisions of Deasy's Act may come to the plaintiff's aid, assuming that the views expressed by Gibson J in Lyle v Smith are correct. Even then, however, the covenant may be one which falls within the description mentioned by Gibson $J$ as incapable of vicarious performance, or so disconnected with the land as not to pass to the assignee, in which case a new landlord will take clear of the obligation created by it.

\section{Leases of the reversion}

The position in Ireland where a new landlord is a lessee of the reversion rather than a transferee of the landlord's estate is not as clear as it might be. In cases in England governed by the Grantees of Reversions Act, the courts held that the Act applied, with the result that

52 Lyle v Smith [1909] 2 IR 58 at 77: "There may be terms depending on personal considerations and not capable of vicarious performance... which might not come within sections 12 and 13; and collateral agreements might be conceived so disconnected with the land and demise that they might not pass to the assignee. Such terms would be construed as not intended - prima facie, at least - to apply or attach to the tenancy proper."

53 Little guidance on the meaning of ss 12 and 13 is given by the other members of the court. None is given by Madden J. Kenny J (at 89) thought it enough to say that the burden of the covenant under consideration was an incident of the tenancy when the defendant purchased the lessee's interest, and as assignee the defendant was liable under s. 12. Lord O'Brien LCJ comes closest to the view that Deasy's Act effected a change in the law, saying (at 70-71): "But taking, as I am told to take, the ipsissima verba of the section [s. 12], is there anything to prevent my giving to them their ordinary meaning? Nothing that I can see . . The Landlord and Tenant Act of 1860 has reference to 'land,' and contracts in reference to land, and the contract under consideration is calculated to affect the subject-matter of demise. The relation of landlord and tenant does not, as it did, rest upon tenure; it now rests upon privity of contract, and if the relation of landlord and tenant rests upon privity of contract, why should not an assignee be bound by an instrument in which the word 'assigns' is used, when he takes under that instrument, and must be presumed to have known its contents? ... The defendant has entered on the subject-matter of the tenancy under an instrument of contract which uses the word 'assigns,' and now endeavours to renounce the contractual obligations which relate to the subject-matter of the contract. This, in my opinion, he cannot do." 
where, after making a lease of land, the lessor made a lease of the reversion, the lessee of the reversion was able to enforce the covenants in the first lease against the lessee under it. The same is the case under the Conveyancing Act, Lush J commenting that "it is not possible now to contend that a lease for years is not the grant of a reversion expectant on the determination of an existing shorter term if the lease is made to take effect in praesenti". ${ }^{56}$ There are no reported decisions as to how the provisions of Deasy's Act apply to leases of the reversion. Bringing lessees of the reversion within the provisions of ss 12 and 13 of Deasy's Act is more difficult than seeing them as entitled to rely on the provisions of the Grantees of Reversions Act or the Conveyancing Act 1881. The Grantees of Reversions Act and the Statute of Reversions both referred to grantees of the reversion. The Conveyancing Act annexes the rent and the benefit of the covenants to the reversion, so that a lessee of the reversion takes his or her interest with benefits annexed. In contrast, ss 12 and 13 of Deasy's Act refer to assignees of the estate of the original landlord or tenant. Taken along with the definition of "landlord" and "tenant" in s. 1, the sections provide that someone who takes an assignment of the estate of the landlord is within the expression "every landlord" in s. 12, and someone who takes an assignment of the estate of an original tenant is within the expression "every tenant" in s. 13, and so is able to enforce covenants made by the tenant. Apropos liability, the sections refer to enforcement of the obligations in a tenancy against assignees of the landlord or of the tenant. If a lessee of the reversion is able by reason of s. 12 to enforce covenants against a tenant, it must surely be the case that the tenant can enforce covenants made by the original landlord against a lessee of the reversion. If that is so, it can only be because the reference to an "assignee" of the landlord in s. 13 includes a lessee of the reversion. Yet if "assignee" includes "lessee", it would seem reasonable to suppose that the same word in s. 12, referring to an assignee of the tenant, would include a lessee of the tenant, which would lead to the position that a landlord should be able to sue subtenants. That is certainly not the case either at common law or under the Conveyancing Act. ${ }^{57}$ Accordingly, if lessees of the reversion are able to enforce covenants against a tenant of the land, and are liable on covenants made by the landlord with such a tenant, yet cannot sue subtenants and are not liable to them, the word "assignee" in s. 12 must be given a different meaning from that given to "assignee" in s. 13.

\section{Breaches before assignment}

Where a breach of covenant by a lessee takes place after the transfer of the reversion to a new landlord, the new landlord can bring proceedings against the lessee by virtue of the statutory provisions mentioned. Where the breach took place before the transfer of the reversion, the position is more difficult. Where the breach which preceded the transfer of the reversion was a breach of a covenant to pay rent, the decision in Flight $\mathrm{v}$ Bentley 58 meant that the new landlord was unable to recover the arrears of rent which existed at the time the transfer took place. Whether the position was the same in the case of other covenants which had been broken by the lessee before the reversion was transferred and whether the law had in any event changed since Flight $\mathrm{v}$ Bentley because of legislative changes were the subjects of the discussion and differing opinions in Re King (deceased). ${ }^{59}$ The view which prevailed is that the relevant provisions of the Law of Property Act 1925 brought about a change and that, because of such provisions, a new landlord was able to sue a lessee for

56 Horn v Beard [1912] 3 KB 181 at 187; see also Cole v Kelly [1920] 2 KB 106.

57 In equity a landlord may be able to bring an action against a subtenant under the doctrine of Tulk v Moxhay (1848) 2 Ph 774; 1 H \& Tw 105. See, p. 375, below.

58 (1835) 7 Sim 149.

$59 \quad$ [1963] 1 All ER 781. 
breaches of covenant which had taken place before the transfer of the reversion, this being so whether the breach was of a covenant to pay rent, ${ }^{60}$ or any other covenant, ${ }^{61}$ though it was open to the parties to arrange matters between them to enable the original landlord to sue. ${ }^{62}$ The provisions of the Law of Property Act considered in Re King (deceased) replaced those in s. 10 of the Conveyancing Act 1881 and in s. 2(1) of the Conveyancing Act 1911.63 The position under s. 10 has recently been held to be the same as that under the 1925 measure, Lightman J saying that the effect of s. 10 is to vest the right to sue in respect of all breaches of covenant occurring before as well as after the date of the transfer in the transferee of the reversion. ${ }^{64}$

If, then, the result of s. 10 of the Conveyancing Act is that a new landlord takes over the ability to sue for breaches of covenant by a lessee which took place before the transfer of the reversion took place, it may be asked whether the new landlord takes over also the liability for the breaches of covenant committed by his or her predecessor. Under s. 11, the obligation of a covenant entered into by a lessor is annexed to the reversionary estate. Garland J had to consider the question under the comparable provisions of the Law of Property Act in Duncliffe v Caerfelin Properties Ltd ${ }^{65}$ and concluded that the new landlord did not by reason of such provisions become liable for a breach of covenant which had been committed before the reversion was transferred. ${ }^{66}$ Thus, it would appear that the effect of the 1881 Act is that a new landlord acquires the right to sue for breaches of covenant committed by the lessee before the transfer of the reversion, but that the new landlord is not liable for breaches of covenant committed before the transfer by his or her predecessor in title.

The question is whether the situation is the same under Deasy's Act. Section 14 provides that:

No landlord . . . being such by assignment . . . shall have the benefit or be liable in respect of the breach of any covenant or contract contained or implied in the lease or other contract of tenancy, otherwise than in respect of such rent as shall have accrued due, and such breaches as shall have occurred or continued subsequent to such assignment, and whilst he shall have continued to be such assignee...

60 London and County (A \& D) Ltd v Wilfred Sportsman Ltd [1971] Ch 764. See also Rickett v Green [1910] 1 KB 253; Kataria v Safeland plc [1998] 1 EGLR 39; Arlesford Trading Co Ltd v Servansingh [1971] 3 All ER 113.

61 Re King (deceased) [1963] 1 All ER 781 (covenant to reinstate).

62 Ibid. at 793 per Upjohn LJ.

63 S. 2(1), which remains in force in Northern Ireland, provides: "Section 10 of the Act of 1881 shall apply to the benefit of every condition of re-entry or forfeiture for a breach of any covenant of condition in a lease, so as to enable the same to be enforced and taken advantage of by the person from time to time entitled, subject to the term, to the income of the whole or any part, as the case may require, of the land leased, although that person became, by conveyance or otherwise, so entitled after the condition of re-entry or forfeiture had become enforceable, provided that he became so entitled as aforesaid after the commencement of this Act."

64 Inland Revenue Commissioners v John Lewis Properties plc [2002] 1 WLR 35 at [6]; for the case on appeal see [2003] Ch 513.

65 [1989] 2 EGLR 38.

66 "[W] hat section 142 [of the Law of Property Act] is talking about is the obligation arising under the lease to observe and perform the repairing covenant as a repairing covenant running with the land and binding the assignee of the reversion. I would find it very hard indeed to construe 'obligation' as it is used in this section as meaning the consequences of a past breach prior to the assignee becoming entitled to the reversion, where that breach has accrued into a cause of action in respect of damage to chattels or other property, and is no longer a continuing breach of the covenant to keep in repair.": Duncliffe v Caerfelin Properties Ltd [1989] 2 EGLR 38 at 39 . 
It would appear from this that the situation under Deasy's Act differs from that under the Conveyancing Act, and that under the former a new landlord is unable to sue for breaches of covenant by the tenant which took place before the new landlord acquired the title, unless the breach continues after the assignment. ${ }^{67}$ Equally, however, (and in this regard apparently in common with the position under the $1881 \mathrm{Act}$ ) the new landlord does not take over liability for breaches of covenant which his or her predecessor committed before the transfer. ${ }^{68}$

The last word concerning the consequences for a new landlord of a breach of covenant committed by his or her predecessor prior to the new landlord acquiring title relates to setoff. Discussion has taken place in a number of recent cases on the question whether, in an action by a new landlord for rent, the tenant can set off damages to which he or she is entitled arising from the claim he or she has as a result of the breach. The matter is considered below.

\section{Conditions}

\section{DEASY'S ACT}

At common law only the original landlord and the landlord's heirs could rely on a condition in a lease, so that a purchaser of the landlord's interest would be unable to rely on conditions as a sanction to enforce payment of the rent and performance of covenants by the lessee. The position changed in Ireland with the enactment of the Statute of Reversions. The Statute of Reversions was repealed by Deasy's Act. Unlike the Conveyancing Act mentioned below, there are no specific provisions in Deasy's Act dealing with conditions. The reason appears to be that s. 12 of the Act is wide enough to avoid the need for separate provision to be made. The section provides that every landlord shall have the same action and remedy against the tenant as the original landlord might have had. If the original landlord could rely on a condition as a remedy for the lessee's failure to perform his or her obligations, it seems clear that the new landlord can do so also. Whether the position is any different in the case of severance of the reversion is considered below.

67 In Patterson v O’Reilly (1882) 10 LR Ir 304 at 307, O’Brien J considered the assignee of a mortgagee of a landlord's estate to have taken nothing by the assignment "except from the date of it, and [to have] acquired no power to serve any notice as to the rents, which were not then vested in him, but merely as to the future rents ... He succeeded to no right, and was subject to no liability except from the date of his deed." Cf. Doyle v Hort (1878) 4 LR Ir 455 at 467 per Palles CB, speaking of the assignee of a lease: "It is clear that being an assignee he can only recover damages for what the Court shall consider to be a breach in his own time." See also Morris v Kennedy [1896] 2 IR 247 at 251 per Holmes J: "When we speak of an assignee being entitled to the benefit or liable to the burden of a covenant that runs with the land, we refer to an unbroken covenant or to a covenant which, although broken, is continuing in its obligation, and of which there is a continuous breach as long as it is unperformed. But there may be a covenant in a lease which touches or concerns the premises demised, which, if broken, is broken finally and once for all. The covenantee is thereupon entitled to bring an action; but a subsequent assignment of his interest in the land does not transfer the right to the assignee. A covenant to pay rent reserved is broken as regards any particular gale when it is not paid at the time appointed; and the amount cannot be recovered from or sued for by an assignee taking under a subsequent assignment. The same rule applies to every covenant to do an act not continuous in its character..."

68 See Riordan and Mulligan v Carroll [1996] 2 ILRM 263 (assignment of reversion dated 1 April 1994); lessee bringing counterclaim in action for possession brought by successor to lessor, alleging breach of implied covenant by lessor, arguing "that the operative date for purposes of the implied covenant to [sic] quiet enjoyment was in or around September 1993 not simply when the lease was assigned on the 1 April 1994 or any later date"; beld, however, "this argument is entirely inconsistent with section 14 of Deasy's Act ....". 


\section{CONVEYANCING ACt 1881}

Section 10 of the Conveyancing Act 1881 deals not only with rent and the benefit of covenants by a lessee in a lease. It deals also with conditions, and provides that the benefit of a condition in a lease, whether a condition for re-entry or otherwise, is annexed to and goes with the reversionary estate in the land. As with recovery of rent and enforcement of covenants, the section provides that the condition can be relied on by the person from time to time entitled to the income of the land leased. There has been some discussion as to whether the section means that a new landlord can avail of a condition in the lease no matter what the terms of the condition are, or whether a new landlord can rely only on a condition which has reference to the subject matter of the lease, ${ }^{69}$ with the view being expressed that the identical wording in s. 141 of the Law of Property Act qualifies covenants but not conditions, and appears intended to allow a new landlord to rely on a condition though unrelated to the land. ${ }^{70}$ If so, s. 10 effected a change, the position under the Grantees of Reversions Act being that a new landlord could forfeit a lease only where the condition touched and concerned the land. ${ }^{71}$

\section{Severance of the reversion}

The inability at common law of a successor in title to part of the land demised to take advantage of a right of re-entry contained in the lease was addressed shortly before the commencement of the period we are considering by s. 3 of the Law of Property Amendment Act 1859. That section applies, however, only where there has been a legal apportionment of the rent reserved by the lease. In the absence of such an apportionment, the position of a successor in title to the landlord, who acquired part only of the land demised by the lease, remained that at common law. The position changed by provisions enacted in the Conveyancing Act. It may have changed in Ireland before that, by reason of provisions in Deasy's Act.

\section{CONVEYANCING ACT 1881}

The effect of severance of the reversion is dealt with in s. 12 of the 1881 Act. For leases made after 1881, the section provides:

Notwithstanding the severance by conveyance, surrender, or otherwise, of the reversionary estate in any land comprised in a lease, and notwithstanding the avoidance or cesser in any other manner of the term granted by a lease as to part only of the land comprised therein, every condition or right of re-entry, and every other condition, contained in the lease, shall be apportioned, and shall remain annexed to the severed parts of the reversionary estate as severed, and shall be in force with respect to the term whereon each severed part is reversionary, or the term in any land which has not been surrendered, or as to which the term has not been avoided or has not otherwise ceased, in like manner as if the land comprised

69 R Megarry and H W R Wade, The Law of Real Property 6th edn (London: Sweet \& Maxwell, 2000), paras 15.058-9.

70 Ibid., para. 15.089 .

71 Ibid., para. 15.088, citing Stevens v Copp (1868) LR 4 Ex 20 (assignee of reversion unable to maintain ejectment pursuant to proviso entitling landlord to re-enter if tenant convicted of offence against the game laws; per Martin, Channell and Cleasby BB, on the ground that the condition did not touch and concern the land, Kelly CB dubitante on the point). See also Horsey Estate Ltd v Steiger [1899] 2 QB 79 and Lewis v American \& Colonial Distributors Ltd [1945] 1 All ER 592. Note, however, the comment of Lord Wilberforce in Shilob Spinners Ltd v Harding [1973] 1 All ER 90 at 96: "Neither of these cases [Stevens v Copp; Horsey Estate Ltd v Steiger] give me satisfaction." 
in each severed part, or the land as to which the term remains subsisting, as the case may be, had alone originally been comprised in the lease.

Three decisions under the comparable provisions of s. 140 of the Law of Property Act 1925 may be mentioned as they afford guidance as to meaning and effect of s. 12 of the 1881 Act.

The first case is Persey v Bazley. ${ }^{72}$ The background to it, however, is the decision in Smith $\mathrm{v}$ Kinsey ${ }^{73}$ in which the Court of Appeal held that following severance of the reversion the owner of one of the severed parts could serve a notice to quit terminating a periodic tenancy in that part. In Persey v Bazley, the landlords had executed deeds transferring part of the land occupied by a tenant to trustees for the purpose of being able to terminate the tenancy in the part of the land transferred by service of a notice to quit by the trustees. May LJ was reluctant to uphold the efficacy of the device unless driven to do so, pointing out that as the trustees held the land on trust for the transferors, it was possible for the land to be restored to the transferors immediately after the notice to quit was given. He was able to avoid the conclusion that the transfer enabled the trustees to terminate the tenancy by holding that the transaction was not properly described as a "severance" within the meaning of s. 140. Unfortunately, other than saying that the section was intended to apply where there was "a real conveyance from the original reversioner", the Lord Justice did not indicate what he considered was meant by the term. ${ }^{74}$

Persey $\mathrm{v}$ Bazley was relied on by the tenant in John $\mathrm{v}$ George, ${ }^{75}$ where landlords had executed a transfer of the reversion in part of the land occupied by a tenant, the transferees being trustees for a member of the landlords' family. Describing Persey v Bazley as “a decision of the Court of Appeal by which I am bound however surprising it may be to a real property lawyer", Judge Moseley QC was able to distinguish the case before him on the ground that in it there was a bona fide transfer of the legal estate in the land transferred to the trustees and a genuine trust for a third party, noting also that the landlords were unable to call for a reconveyance of the land to them.

Persey v Bazley is important for what it says about "severance" in s. 140 of the Law of Property Act, as the same word appears in s. 12 of the Conveyancing Act. Beyond that, however, the efficacy of the device of transferring the reversion in part of the land in order to terminate a periodic tenancy in the land transferred needs to be considered further. The problem is that s. 140 of the Law of Property Act contains a provision for which no counterpart exists under the preceding legislation still applicable in Northern Ireland. By s. 140(2) it is declared that, for the purposes of the section, a right of re-entry includes a right to determine the lease by notice to quit. Shortly before that provision was enacted it had been held that a transferee of part of the land occupied by a tenant under a periodic tenancy was unable to terminate the tenancy in the part the transferee had acquired, ${ }^{76}$ and the provision was seen as intended to reverse that decision. ${ }^{77}$

72 (1983) 47 P \& CR 37.

73 [1936] 3 All ER 73.

74 See (1983) 47 P \& CR 37 at 44: "I am quite satisfied, had the mind of the draftsman been directed to the circumstances which have arisen in this case, that he would not have intended section 140 to apply. In my opinion this section was intended to deal with the situation where there has been a real conveyance from the original reversioner and thus a severance. It would be unwise and I do not propose to try to define what is meant by the word 'severance' in section 140 of the Act. Each case will have to be dealt with on its merits as and when it arises. It is sufficient for the purposes of deciding the present appeal for me to say that in my opinion the two conveyances ... did not effect such a severance."

75 [1995] 22 EG 146. The decision was reversed on appeal on another ground: see (1996) 71 P \& CR 375 and p. 372 , below.

76 Re Bebington's Tenancy [1921] 1 Ch 559.

77 See Smith v Kinsey [1936] 3 All ER 73. 
The last case, useful for illustration purposes, is Epron International Ltd v Lilachall Ltd, ${ }^{78}$ which concerned an estate comprising two buildings, known respectively as The Grange and The Park. Each building comprised residential accommodation, The Park having thirtythree residential units and The Grange fourteen. Each unit was the subject of a lease from the owner of the estate. Later the reversion in The Park became vested in Epron, and that in The Grange in Lilachall. The question for the court was whether Epron was entitled to recover from the lessees of units in The Grange a portion of the costs incurred by Epron in maintenance of The Park, there being a covenant in each lease by the lessee to pay a service charge. The basis of Epron's argument was that the leases of the units in The Grange conferred on the lessees rights of way over land belonging to Epron as owner of The Park, and that there had been a severance of the reversion of each lease in The Grange, Epron's ownership of the land over which the easements were exercisable being a severed part of the reversion for the purposes of s. 140 of the 1925 Act. That being so, the benefit of the lessees' covenants to pay a service charge could be enforced by Epron to recover expenditure relating to the easements. Rattee J agreed, holding that the benefit of the covenant to pay part of the costs of maintaining The Park remained annexed to the reversion to The Park expectant on the termination of the easements over it, and was enforceable by Epron as owner of that reversion.

\section{DEASY'S ACT}

Before the provisions of the Conveyancing Act were enacted, the House of Lords in Liddy $\mathrm{v}$ Kenned $y^{79}$ had considered whether the provisions of Deasy's Act had made any change to the position at common law regarding the effect of a severance of the reversion. The issue was whether a notice served by two brothers pursuant to the terms of a lease was effective to entitle them to possession of the land demised by the lease. The lease had been made by one of the brothers who was then sole owner of the land. A year later he executed a deed in which he covenanted to stand seised of the land to the use of himself and his brother as tenants in common. Arguing that the notice was ineffective, the tenant contended there had been a severance of the reversion, the effect of which was to destroy the right to resume possession under the lease. Rejecting the argument, Lord Hatherley LC found assistance in s. 44 of Deasy's Act, ${ }^{80}$ but more fundamentally saw the Act as intended to get rid of technicalities which had been found to lead to injustice, considering the argument advanced as within such criticism. ${ }^{81}$ The Lord Chancellor went on to hold that the Act meant that "all the persons interested as one collective landlord are to have all the benefits which belonged to those from whom they derive their title". ${ }^{82}$ For Lord Westbury also, Deasy's Act was intended to make, and had made, matters more straightforward: the correct construction of the Act was that the assignee "is to have the same right which the assignor had at the time of the assignment; and if the assignor could have entered for breach of the condition by force of the Statute, the assignee may do the same." 83

78 Unrep, 8 May 2001, Rattee J.

79 (1871) LR 5 HL 134.

80 The section provides that: "The surrender to or resumption by a landlord, or eviction of any portion of the premises demised by a lease, shall not in any manner prejudice or affect the rights of the landlord, whether by action or entry, or ejectment, as to the residue of said premises."

81 (1871) LR 5 HL 134 at 143: "It appears to me that this statute has been framed for the express purpose of removing some of the technical difficulties which stood in the way of justice, and which, though devised originally with logical regard to consequences, have been found in practice to involve far more frequently the failure of justice than to secure any beneficial result to the parties."

82 (1871) LR 5 HL 134 at 146.

83 Ibid. at 154. 


\section{Whom to sue}

In the earlier part of this examination of the law relating to new landlords, we saw that the original tenant remained liable under any express covenants into which he or she had entered, and could be sued for breach of such covenants notwithstanding that the tenancy had become vested in an assignee. The position was not affected by the Conveyancing Act, but provisions in Deasy's Act need to be considered.

So far as recovery of rent is concerned, the right to bring an action for rent conferred by s. 45 of the Act entitles the landlord to recover rent "from the tenant of such lands at the time of the accruing of the said rent". No action therefore will be possible under the section against the original tenant where the arrear accrues after the tenant assigns the tenancy: the action must be against the assignee who has the leasehold estate when the rent accrues. It is thought, however, that the section has no relevance to an action brought upon a covenant by the lessee to pay the rent, so that if such a covenant exists, the lessee will remain liable notwithstanding the provisions of the section. Certainly, prior to the abolition of the forms of action, the original lessee would have been liable in an action of covenant, though an action of debt against the original lessee might not have succeeded. In addition, an action based on a covenant to pay the rent is not one for the rent, but for damages because the rent has not been paid, so that, in speaking of the entitlement to recover rent in arrear, the section leaves untouched any entitlement to damages which may exist independently by reason of a covenant to pay the rent.

Section 16 of Deasy's Act makes provision for the discharge of an original lessee from future liability to the lessor. It provides that:

From and after any assignment hereafter to be made of the estate or interest of any original tenant in any lease, with the consent of the landlord, testified in manner specified in section 10 , the landlord so consenting shall be deemed to have released and discharged the said tenant from all actions and remedies at the suit of such landlord, and all persons claiming by, through, or under him, in respect of any future breach of the agreements contained in the lease, but without prejudice to any remedy or right against the assignee of such estate or interest.

The section applies to leases, and so has no application where a tenancy is created otherwise than by instrument in writing. If, however, it does apply, the section enables a lessee to rid him or herself of liability for any breach of the agreements in the lease occurring after the lessee assigns the lease, if the lessee obtains the consent of the lessor to such assignment. Such consent must be testified in the manner specified in s. 10, that is by the landlord being an executing party to the instrument of assignment, or by indorsement on or subscription of such instrument. This, however, invites a question as to the effect of a consent by the landlord in any other way, for example where the landlord signifies consent by letter, email, telephone call, or any other means not mentioned in the section. A consent in accordance with the terms of the lease, though not in accordance with the provisions of s. 10, was sufficient for the purposes of that section in In re Ulster Permanent Building Society, ${ }^{84}$ and it was suggested in Craigdarragh Trading Co Ltd v Doherty 85 that a waiver of a covenant by a landlord might be effective by way of estoppel though not in writing, as required for the purposes of s. 43 of Deasy's Act, so that the answer to the question may be that consent by the landlord, testified otherwise than in accordance with s. 10, may yet be sufficient to discharge an original lessee from future liability. Although, so far as successors in title to the landlord consenting are concerned, considerations may have to be taken into account which 
would not be necessary if the terms of s. 16 as to the manner in which consent is required to be shown are complied with.

\section{Defences}

Assuming that a new landlord is able to establish that rent has not been paid, or that a breach of covenant has been committed, two matters may be considered which may be relevant in an action brought by the new landlord. In each case, the question is whether a new landlord may be affected by matters which took place between his or her predecessor and the tenant.

\section{SET-OFF}

Assuming that a new landlord can sue on covenants entered into by the tenant, the question arises whether the tenant can set off, against the new landlord's claim, any claim the tenant has by reason of a breach of a covenant by the original landlord. The matter has been considered recently on two occasions by the Court of Appeal in England. Each case was concerned with equitable set-off, the tenant's claim being for an unliquidated amount. ${ }^{86}$ In Ireland, set-off between landlord and tenant is provided for, however, in s. 48 of Deasy's Act, and it will be convenient to consider the position under that section before looking at the cases mentioned.

Section 48 of Deasy's Act provides that:

All claims and demands by any landlord against his tenant in respect of rent shall be subject to deduction or set-off in respect of all just debts due by the landlord to the tenant.

Without considering the ambit of the section, ${ }^{87}$ it seems clear from the use of the definite article when referring to setting off just debts due from "the landlord" in an action by "any landlord" that the landlord indebted is one and the same person as the person who is bringing the claim in respect of rent against the tenant. As such, the section appears to be inapplicable in the situation under consideration of a tenant who wishes to set off claims he or she has against a former landlord in an action by the landlord's successor.

Which brings us to Muscat v Smith. ${ }^{88}$ The case concerned an action by the successor in title to a landlord for possession of premises to which the Rent Acts applied. At the time of the transfer of the reversion, arrears of rent had accumulated, as the tenant had ceased

86 As Buxton LJ explained in Muscat v Smith [2003] EWCA Civ 962 at [40], equitable set-off is so called "because, but only because, it permits the setting-off in an action at law of unliquidated claims that, before 1873 , could only be pursued at law by a separate action, and could only affect the proceedings at law by way of an equitable injunction. The institution does not otherwise appeal to any specifically equitable doctrine, and in particular does not permit of any deduction from or reduction of the claim other than by the assertion of a counterclaim that is sufficiently connected with or related to the original claim." The advantage of equitable set-off for a tenant is, as Buxton LJ indicates, that it allows the tenant to set off unliquidated claims against claims by a landlord, provided the claims of the parties meet the requirement of being sufficiently closely connected to each other. For the differences between legal set-off and equitable set-off, and their consequences so far as landlord and tenant are concerned, see Fuller v Happy Shopper Markets Ltd [2001] 1 WLR 1681; Eller v Grovecrest Investments Ltd [1995] QB 272.

87 Two points, however, may briefly be noted. Unlike equitable set-off, the section allows a tenant to set off liquidated sums only against the landlord's claim: MacCausland and Kimmitt v Carroll and Dooley (1938) 72 ILTR 158; Riordan and Mulligan v Carroll [1996] 2 ILRM 263; see also Leopardstown Club Ltd v Templeville Developments $L t d$ [2006] IEHC 133. Secondly, the section does not enable a tenant to set off monies due from the landlord in an action for possession under s. 52 of Deasy's Act to reduce the amount owing to the landlord below the amount referred to in that section: see Wilson v Burne (1888) 24 LR Ir 14; Riordan and Mulligan v Carroll [1996] 2 ILRM 263.

88 [2003] EWCA Civ 962. 
paying rent because of the landlord's failure to carry out repairs. Following the transfer of the reversion, and a separate assignment to the new landlord of the arrears of rent, the new landlord terminated the tenancy by notice to quit. In order to recover possession, however, the landlord had to show arrears of rent existed and that it was reasonable for the court to make an order for possession. The tenant sought to defend the action by setting off a claim for damages for breach by the original landlord of a repairing covenant. ${ }^{89}$ The decision of the Court of Appeal, that the tenant had a right to set off his claim, has been criticised, ${ }^{90}$ and remarks in the case by Sedley LJ, insofar as they suggested that this right extends to rent accruing after the transfer of the reversion, have elsewhere been described as "obiter, a little Delphic .... inconsistent with two Court of Appeal decisions not cited to him, and in conflict with the views expressed on the topic in the leading textbooks". 91 Nonetheless, Buxton and Ward LJJ came to the same decision in the case, which suggests that closer analysis may be appropriate.

The basis of Sedley LJ's decision that a tenant should be allowed to set off a claim he had arising out of a breach by the original landlord against a claim by the new landlord was that "the debt, a chose in action, vest[ed] in [the new landlord] as assignee subject to all equities which were available to [the tenant] against the assignor". ${ }^{2}$ Buxton LJ was of similar opinion, adding that he saw no reason for thinking that s. 141 of the Law of Property Act $1925^{93}$ was intended to exclude the rule that an assignee of a chose in action took subject to equities from a case where the landlord asserted a claim as an assigned chose in action. ${ }^{94}$ Ward LJ's short judgment is likewise based on the assignee of a chose in action taking the chose subject to equities affecting it.

The view that a tenant can, in an action by a new landlord, set off a claim the tenant has arising out of a breach of covenant by a previous landlord, because the new landlord has acquired a chose in action subject to equities affecting it, was discussed by the Court of Appeal again in Edlington Properties Ltd $\mathrm{v} J \mathrm{H}$ Fenner $\&$ Co Ltd. ${ }^{95}$ It is the judgment of Neuberger LJ in the case which contains the criticism of the views of Sedley LJ already quoted. In the case, a tenant sought to set off, against a claim by an assignee of the reversion for rent accruing after the transfer of the reversion, a claim for damages arising out of the breach of an obligation of the original landlord, contained not in the lease, but in the agreement preceding it. The tenant's case was based on two alternative propositions: first, that the transferee of the reversion took subject to the equities which were available against the transferor; and secondly, that the tenant's right of equitable set-off against the original landlord was a right which ran with the land and was therefore enforceable against a

89 Cf. Riordan and Mulligan v Carroll [1996] 2 ILRM 263.

90 R Derham, "Equitable set-off: a critique of Muscat v Smith" (2006) 122 LQR 469.

91 Edlington Properties Ltd v J H Fenner \& Co Ltd [2006] EWCA Civ 403 at [41] per Neuberger LJ.

92 [2003] EWCA Civ 962 at [31].

93 Corresponding to s. 10 of the Conveyancing Act 1881.

94 [2003] EWCA Civ 962 at [54].

95 [2006] EWCA Civ 403. 
transferee of the reversion. ${ }^{96}$ Neuberger LJ thought neither proposition correct, at least where the transfer was at arm's length, ${ }^{97}$ concluding that

$[w]$ here the reversion to a lease is transferred, a tenant cannot set off, against rent falling due after the transfer, a claim for damages he has arising out of a breach by his original landlord of the lease, let alone of the agreement pursuant to which the lease was granted, unless of course the lease specifically provides that he should have that right. ${ }^{98}$

Where does this leave Muscat $\mathrm{v}$ Smith? The case was described by Neuberger LJ as "not entirely easy to analyse" 99 and it was pointed out both that a number of relevant authorities had not been cited to the court in it, and that there appeared to be a difference between the judgments of Sedley and Buxton LJJ. Nonetheless, as in Edlington Properties, the landlord's action was for rent accruing after the transfer of the reversion, Muscat v Smith was distinguishable. Insofar as the result of the two cases is that a right of set-off, for damages arising as a result of a breach of covenant by the landlord before the transfer of the reversion, exists against a claim for rent accrued at the date the reversion is transferred, but not against a claim for rent accruing thereafter, Neuberger LJ explained:

The right to recover the accrued rent, although it goes with the reversion, is a chose in action, whereas the right to recover future rent is not: it is simply an incident of the reversion. The distinction is readily understandable in terms of principle and it is easily reconcilable with commercial common sense. When the rent accruing due before the transfer actually fell due it can be said to have been impeached by the right of set-off because the person then entitled to recover the rent was the immediate landlord, whereas the same point cannot be made in relation to the rent accruing due after the transfer. ${ }^{100}$

\section{ESTOPPEL}

A similar question to that considered in the preceding section is whether a successor in title to the landlord can be bound by reason of statements or actions by the landlord's predecessor. If, for example, the original landlord agrees to accept a reduced rent from the tenant, the landlord may be prevented from requiring payment of the full rent until notice that the full rent is required again is given to the tenant. ${ }^{101}$ But would the statement be binding on a transferee from the landlord? If the answer to that is yes, ${ }^{102}$ it would seem just that the landlord's successor should be able to take advantage of a situation where the tenant

96 [2006] EWCA Civ 403 at [9].

97 Ibid. at [10]. Apropos the first proposition, Neuberger LJ said that a comparison of the statutory provisions concerning assignment of choses in action and the provisions for the transfer of the benefit and burden of leasehold covenants showed that, under the former (Law of Property Act 1925, s. 136 (cf. Judicature (NI) Act 1978 , s. 87)), the right of a debtor to rely on any rights of set-off was expressly preserved. He explained, however, that the right of a transferee of the reversion to recover rent was an incident of the right of ownership of the reversion, and different from the right of an assignee of an ordinary debt, and accordingly might have different features from the right to recover a debt. As to the second proposition, the Lord Justice explained that a purchaser of land, including a transferee of the reversion, took subject to an equitable right only where that right was an interest in land, and that a tenant's right to damages was not an interest in land. The contention that the liability to pay damages was one which ran with the reversion was considered both contrary to principle and difficult to reconcile with Duncliffe v Caerfelin Properties Ltd [1989] 2 EGLR 38.

98 [2006] EWCA Civ 403 at [64].

99 Ibid. at [35].

100 Ibid. at [47].

101 Central London Property Trust Ltd v High Trees House Ltd [1947] KB 130.

102 See Hazel v Ashtar [2001] EWCA Civ 1883 at [24]. 
is prevented from denying something by reason of something the tenant said to a preceding owner of the landlord's interest. It is clear that a successor in title to a landlord may be estopped from denying a state of affairs by something the successor him or herself has said to the tenant, or from something the successor has done. The estoppel here, however, has nothing to do with the landlord's predecessor. What is to be considered is where the events which have taken place occurred before the transfer of the reversion to the new landlord.

Discussion of the various principles at work - waiver, forbearance or estoppel - and whether, and if so how, the situation of a successor in title differs according to which principle, or which type of estoppel, applies in the particular case, is outside the scope of the present investigation. ${ }^{103}$ Suffice to say that it appears from the cases that a successor in title to a landlord may be entitled to take advantage of an estoppel operating in favour of the original landlord, and equally that a successor in title to the landlord may be bound by an estoppel operating against the original landlord. Most of the cases appear to concern the latter situation. An exception is Culbertson v Irving, ${ }^{104}$ where a successor in title to the landlord was successful in an action of covenant against the lessee, the lessee's defence, that the original landlord had no title to make the lease (and accordingly that the plaintiff had no title on which to base the action), being of no avail as the lessee was estopped from denying his lessor had title. ${ }^{105}$ Before concluding that a successor can avail of an estoppel arising from something said to his or her predecessor, the differing views expressed in Brikom Investments Ltd v Carr ${ }^{106}$ need to be taken into account. Such views concerned an assignee of the lessee and the original landlord, rather than an assignee of the reversion and the original tenant, but there would seem to be no difference between the two situations: the question is whether the assignee can take advantage of the statement made. Lord Denning MR thought he could; ${ }^{107}$ Cumming-Bruce LJ thought not. ${ }^{108}$ Roskill LJ too was unwilling to concur with the view expressed by Lord Denning. ${ }^{109}$

So far as a successor in title to the landlord being bound by estoppels operating against his or her predecessor is concerned, a number of cases illustrate the possibility that the successor will be in no better position than the predecessor. In John v George, ${ }^{110}$ trustees to whom the landlords had transferred the reversion were bound by an estoppel operating against the landlords, thereby preventing the trustees from determining the tenancy by service of a notice to quit. The trustees were voluntary transferees, but purchasers for value were held to be bound by an estoppel operating against their predecessors in Keith v Gandia \& Co Ltd ${ }^{111}$ and in Hammersmith and Fulham LBC v Top Shop Centres Ltd, ${ }^{112}$ Warner J in the latter saying that any estoppel operating against the defendants' predecessors "of course binds their successors in title". ${ }^{113}$ Such also was the view of Lord Denning MR, obiter, in

103 For explanation of the various principles, see Chitty on Contracts 28th edn (London: Sweet \& Maxwell, 1999), paras 3.076-106; S Wilken and T Villiers, The Law of Waiver, Variation and Estoppel 2nd edn (Oxford: OUP, 2002).

104 (1860) 6 H \& N 135.

105 See also Ward v Ryan (1875) IR 10 CL 17.

106 [1979] QB 467.

107 Ibid. at 484 .

108 Ibid. at 490: "I do not see how an assignee can claim the benefit of an estoppel founded on a promise made to somebody else, even though that other person is the assignor who is assigning the unexpired term of the lease."

109 Ibid. at 486.

110 (1996) 71 P \& CR 375.

111 [1904] $1 \mathrm{Ch} 774$.

112 [1989] 2 All ER 655.

113 Ibid. at 668. 
Brikom Investments Ltd $\mathrm{v}$ Carr, ${ }^{114}$ on the basis that "It would be most unjust and unfair if [a purchaser of the reversion] could go back on the promise. Equity would not allow him to do it." More recently, Neuberger J concluded that the authorities supported the proposition that once an estoppel (perhaps other than estoppel by representation) is established as between a landlord and a tenant, then it would normally bind their respective successors in title. As a matter of logic the same conclusion must apply to a convention which in due course may give rise to an estoppel. ${ }^{115}$

\section{Other principles}

The provisions which have been examined above are the obvious ones to be considered in connection with the ability of a new landlord to sue for rent or for breach of covenant, or in determining whether he or she becomes liable to the tenant on covenants undertaken by the original landlord with the tenant. There are, however, other principles which may be relevant. Some of these may assist a new landlord in circumstances where those already considered will not. Others may operate to the disadvantage of a new landlord, by subjecting the new landlord to liability where, on the basis of the law considered so far, no such liability would arise.

\section{Collateral CONTRACTS}

If there is a collateral contract between the parties to the tenancy, it appears that a new landlord may be bound by the terms of it. In his judgment, at first instance, in Business Environment Bow Lane Ltd $\mathrm{v}$ Deanwater Estates Ltd, ${ }^{116}$ Briggs $\mathrm{J}$ explained, in a passage approved by the Court of Appeal, that a collateral contract might arise " $[\mathrm{w}]$ here one party ... says that he will only enter into the written contract or, as here into the lease, if the other party . . . agrees not to enforce some provision of it against him in specific circumstances." 117 An example is Brikom Investments Ltd v Carr, ${ }^{118}$ where a landlord was unable to recover a contribution towards the cost of repairs from a lessee who had entered into a lease containing a covenant on her part for contribution, on the basis that prior to the lease the landlord had represented that it would carry out the repairs at its own expense. ${ }^{119}$ In Business Environment Bow Lane Ltd $\mathrm{v}$ Deanwater Estates Ltd, ${ }^{120}$ the Court of

114 [1979] QB 467 at 484.

115 PW \& Cov Milton Gate Investment Ltd [2004] Ch 142 at [196]. The most recent example of an estoppel being prayed in aid by a lessee against a transferee of the reversion, where the estoppel alleged was based on a statement made by the transferee's predecessor, is Business Environment Bow Lane Ltd v Deanwater Estates Ltd [2007] EWCA Civ 622. It was common ground, however, before the Court of Appeal that the lessee's defence, based on estoppel, to the transferee's action for breach of covenant added nothing to its defence based on a collateral contract said to exist at the time the lease was made, and the case proceeded on the question of whether a collateral contract existed.

116 [2006] EWHC 3363 (Ch).

117 Ibid. at [7]. For collateral contracts generally, see De Lasselle v Guildford [1901] 2 KB 215; Heilbut Symons \& Co $v$ Buckeleton [1913] AC 30; J Evans \& Son (Portsmouth) Ltd v Andrea Merzario Ltd [1976] 1 WLR 1078; Esso Petroleum Co Ltd v Mardon [1976] 2 All ER 5; Howard Marine \& Dredging Ltd v A Ogden \& Sons (Excavations) Ltd [1978] QB 574; Inntrepreneur Pub Co Ltd v East Crown Ltd [2000] 3 EGLR 31.

118 [1979] QB 467.

119 For other cases involving collateral contracts in disputes between landlord and tenant see De Lasselle v Guildford [1901] 2 KB 215 (landlord liable to tenant for representation as to state of drains of demised premises made prior to delivery of counterpart lease by tenant); City \& Westminster Properties (1934) Ltd v Mudd [1958] 2 All ER 733 (landlord unable to forfeit lease on account of breach of covenant to use premises only for business, because of representation made at time of lease that landlord would not object to tenant's continued residence in premises). See also Riordan and Mulligan v Carroll [1996] 2 ILRM 263.

120 [2007] EWCA Civ 622. 
Appeal, disagreeing with the conclusion of Briggs J on the facts, held that no such contract had been established. The significance of the case for present purposes lies in the comments of Morritt $\mathrm{C}$ in the Court of Appeal on the question whether such a contract would, if established, bind successors in title to the landlord. The Chancellor said that: "It must also be recognised that [a promise said to be binding as a collateral contract] may be binding on successors in title of both parties without the need for notice or registration as a Land Charge or in the Land Registry." ${ }^{21}$ Morritt C went on to say that the basis on which such a contract would bind successors was either estoppel or a contractual waiver, according to which view was taken of the reasoning in Brikom Investments Ltd v Carr. ${ }^{122}$

\section{RUNNING OF COVENANTS AT LAW}

Sections 12 and 13 of Deasy's Act allow a successor in title to the landlord to sue, and make the successor liable upon, covenants contained in the lease or contract of tenancy. Section 10 of the Conveyancing Act speaks of covenants "therein [i.e. in the lease] contained". In each case, the covenants to which the sections apply are covenants made between landlord and tenant. For covenants made outside the lease the sections have no application. Nor will they apply to covenants entered into by third parties, whether in the lease or outside it. Cases where, for example, a covenant is entered into by a surety guaranteeing payment of the rent and performance of the covenants by the tenant will not fall within the provisions of the sections, whether the covenant by the surety is contained in the lease or in a separate deed. A successor in title to the landlord wishing to rely on the benefit of a covenant made by a surety with the original landlord could of course take an express assignment of the benefit of the covenant along with the transfer of the reversion, but in the absence of such an assignment, the successor will be unable to rely on the provisions mentioned in order to enforce the covenant against the surety. Such was the difficulty for which happily a solution was found in Kumar v Dunning, ${ }^{123}$ in which the Court of Appeal, having reviewed a number of earlier decisions at first instance, ${ }^{124}$ held that a surety covenant was one which touched and concerned land of the covenantee, namely the reversion on the lease, so that a successor in title to the landlord who had acquired the reversion would have been able to enforce the covenant without having to rely on statutory provisions. ${ }^{125}$ The basis on which the court in Kumar v Dunning found the new landlord could have enforced the surety covenant was that the covenant was one which touched and concerned the reversion to the lease, and that the new landlord as assignee of the reversion took the benefit of the covenant automatically. The statutory provisions equivalent to ss 10 and 11 of the Conveyancing Act had no bearing on the matter, since there was neither privity of contract nor privity of estate between the surety and the new landlord. Nonetheless, following Smith $\mathrm{v}$ River Douglas Catchment Board, ${ }^{126}$ Browne-Wilkinson V-C was able to hold that the benefit of the covenant ran to the successor in title of the reversion. The decision has been approved by the House of Lords, ${ }^{127}$ which has subsequently held that a transferee of the

121 [2007] EWCA Civ 622 at [42].

122 See p. 372, above.

123 [1987] 2 All ER 801.

124 Pinemain v Welbeck International Ltd (1984) 272 EG 1166; Re Distributors and Warehousing Ltd [1986] BCLC 129; Coastplace Ltd v Hartley [1987] 2 WLR 1299.

125 In Ireland, the same result had been reached by White J some time earlier in Berryman v McCrum (1907) 42 ILTR 19, on the basis that "looking at the contract as a whole, it is clear that it was intended to subsist for the benefit of all successive and continuing landlords who should represent the lessor's interest in the fee".

126 [1949] 2 All ER 179.

127 P \& A Swift Investments v Combined English Stores Group plc [1988] 2 All ER 885. 
reversion was able to enforce a covenant by a surety to take a new lease should the original lease be disclaimed on the tenant's insolvency. ${ }^{128}$

A similar problem to that which exists for a landlord may exist for a tenant, as where the landlord undertakes obligations in an instrument other than the lease, which the tenant now wishes to enforce against a new landlord. If the obligation in question is contained in an instrument other than the lease, the provisions of s. 13 of Deasy's Act will not apply. The solution in Kumar v Dunning will be of no use, since while the benefit of a covenant can run at common law, the burden does not, so that a new landlord will not be bound by the obligation. One possibility might be to contend that, while not contained in the lease, the obligation is yet contained in the "contract of tenancy" mentioned in s. 13, such contract being comprised in more than one document. Fortunately, the provisions of s. 11 of the Conveyancing Act may avoid the need to argue the point. Unlike s. 10 of the 1881 Act, which applies to covenants by a lessee contained in the lease, s. 11 refers merely to the obligation of a covenant by the lessor, without mentioning where such covenant is to be found. Accordingly, in Weg Motors Ltd v Hales, ${ }^{129}$ decided under the comparable provisions of the Law of Property Act, an option granted by a landlord to renew a lease was held binding on a successor in title to the landlord, notwithstanding that the option was contained in an instrument other than the lease, executed at the time the lease was made. ${ }^{130}$ Likewise, an undertaking, contained in a letter, by which a lessor agreed to accept a surrender of a lease was held to be enforceable against a successor in title to the lessor in System Floors Ltd $\mathrm{v}$ Ruralpride Ltd. ${ }^{131}$ For the same reason, in Lotteryking Ltd $\mathrm{v}$ AMEC Properties $L t d,{ }^{132}$ a lessee concerned about its ability to enforce an undertaking by the lessor in a collateral agreement to carry out remedial work was refused an injunction to restrain the sale of the landlord's interest to a purchaser, the court considering the lessee would be able to enforce the undertaking against the purchaser. ${ }^{133}$

\section{RUNNING OF COVENANTS IN EQUITY}

Under the doctrine of Tulk $\mathrm{v}$ Moxhay, ${ }^{134}$ a successor in title to someone who undertakes an obligation in a covenant may be restrained from acting in contravention of the covenant. Equally, a successor in title to the person with whom a covenant is made may under the doctrine be able to enforce the covenant. From this summary of the doctrine it would seem that it could be applied in the case of a covenant contained in a lease, so enabling a new landlord to sue a tenant on covenants by the tenant, and, equally, making a new landlord liable to be restrained from acting in contravention of covenants undertaken in the lease by his or her predecessor. The doctrine is concerned only, however, with negative covenants, ${ }^{135}$ so that many obligations commonly found within a lease, whether on the part of a landlord or on the part of a tenant, such as a covenant to carry out repairs, will not fall within the scope of the doctrine. Nonetheless, in cases where the relevant obligation meets

128 Coronation Street Industrial Properties Ltd v Ingall Industries plc [1989] 1 All ER 979.

129 [1962] Ch 49.

130 And notwithstanding also that the option was not made under seal.

131 [1995] 07 EG 125.

132 [1995] 28 EG 100.

133 In reaching his decision that the lessee would suffer no prejudice from the transfer of the reversion, Lightman J considered that any right of set-off available to the lessee would be available against a purchaser from the lessor. His views on this point are discussed in Edlington Properties Ltd v J H Fenner \& Co Ltd [2006] EWCA Civ 403 (see p. 370, above).

134 (1848) $2 \mathrm{Ph} 774 ; 1 \mathrm{H} \&$ Tw 105.

135 Haywood v Brunswick Permanent Building Society (1881) 8 QBD 403. 
this requirement, the doctrine would seem to provide an alternative ground for establishing liability as between tenant and new landlord.

There is, however, a difficulty. The doctrine operates on the basis that the covenant in question is a burden on land of the covenantor, and is a benefit to land of the covenantee. The principle that there must be dominant land and servient land was not originally the basis of the doctrine, but became established at the beginning of the twentieth century. ${ }^{136}$ The requirement means that someone who does not own land cannot rely on the doctrine to enjoin a successor in title to the covenantor from acting in contravention of the covenant. ${ }^{137}$ Equally, someone other than the person who enters into the covenant will not be affected by it unless he or she has become the owner of land on which the covenant is a burden. In the context of the situation of a new landlord and a tenant, the question is whether this requirement is fulfilled. The problem centres on the question whether the landlord's interest in the land demised constitutes land for the purposes of the doctrine, or whether the doctrine requires that the land in question must be corporeal property. The basis of the decisions in Kumar v Dunning and $P \& A$ Swift Investments v Combined English Stores Group plc ${ }^{138}$ is that the landlord's interest counts as land for the purposes of the rule at common law that the benefit of a covenant passes to successors in title of the covenantee where that covenant touches and concerns land of the covenantee, but that is not to say that the same must be the case with the doctrine in Tulk v Moxhay. A number of cases can be found in which landlords have been able to rely on the doctrine to restrain breaches of covenants in leases, ${ }^{139}$ but for the most part these were decided before the rule requiring the plaintiff to have land benefited by the covenant was established. Nonetheless, statements can be found in modern cases supporting the view that the landlord's interest is sufficient for the purposes of the doctrine. ${ }^{140}$ That being the case, a new landlord should be able to rely on the doctrine to restrain a breach of covenant by the tenant, assuming the various requirements of the doctrine are met. Equally, the doctrine might enable a tenant to prevent a new landlord acting in contravention of a covenant entered into by the original landlord. This situation is more complicated, however, since the covenant will not only have to be negative in substance, but will also have to be one which meets the requirement that it touches and concerns the land of the covenantor; in this case the landlord's interest in the land demised.

\section{Conclusion}

This examination of the law applicable where a landlord transfers his or her interest to a new party began by pointing out the difference between the case where a tenancy has been created and that where the arrangement between the parties lies merely in contract. The law of contract has in recent years come to play a more significant role in resolving disputes between landlord and tenant, in order to arrive at results which avoid injustices or shortcomings which might otherwise exist. The cases in which principles of the law of contract have been applied, however, in such disputes have yet to explore the situation

136 Formby v Barker [1903] 2 Ch 539; London County Councilv Allen [1914] 3 KB 642.

137 London County Councilv Allen [1914] 3 KB 642.

138 [1988] 2 All ER 885.

139 Parker v Whyte (1863) 1 H \& M 167; Tritton v Bankart (1857) 56 LT 306; Hallv Ewin (1887) 37 Ch D 74; Teape v Douse (1905) 92 LT 319.

140 See Northern Ireland Carriers Ltd v Larne Harbour Ltd [1981] NI 171; Hemingway Securities Ltd v Dunraven Ltd (1994) 71 P \& CR 30. 
where a third party is involved, such as a new landlord. ${ }^{141}$ The law which has been examined in the foregoing discussion deals with precisely that situation: it ensures that obligations undertaken by the parties to one particular type of contract (a contract of tenancy) will be enforceable by and against persons other than those who entered into that contract. The law contained in the Grantees of Reversions Act and the Conveyancing Act falls short, however, of providing that a new landlord simply steps into the shoes of his or her predecessor: not all benefits enjoyed by the original landlord, and not all burdens to which the original landlord was subject, will affect a new landlord. The limitation that covenants must touch and concern the land, or have reference to the subject matter of the lease, means that a new landlord is not simply substituted for his or her predecessor in the eyes of the law. In Ireland, the situation comes nearer to that, if the observations in Lyle v Smith are to be given effect. Even then, however, there is a reticence to say that what the original landlord promised, a new landlord must do. Lyle $\mathrm{v}$ Smith recognises that there may be obligations incapable of vicarious performance, either because they are dependent on the person of the original landlord or because they are so unrelated to the tenancy that they cannot have been intended to affect others than the original parties to the tenancy. With regard to obligations incident to the tenancy (to use the expression in Borrowes v Delaney), no difficulty exists, and it is hard to see why one should. If someone buys the interest of a landlord with the intention of reaping the benefits of it, why should the purchaser not have to accept the burdens that go with it also? The declared basis of the law of landlord and tenant in Ireland is the contract of the parties. If the aim of the legislature was to put the law in Ireland on a modern footing, getting rid of feudal considerations and technicalities, ${ }^{142}$ why should the bargain entered into between a landlord and a purchaser of his interest be one to which such technicalities continue to apply? ${ }^{143}$

Leaving that question aside, the situation which exists at present leaves something to be desired. The law applicable in some situations involving new landlords is contained in statutory provisions, and in other cases where such provisions do not apply, in rules developed either at common law or in equity. And just for good measure, more than one statute exists to deal with some instances. In the main, the provisions of Deasy's Act seem more favourable to new landlords wishing to enforce obligations undertaken by tenants, and for tenants wishing to enforce against a new landlord obligations undertaken by their original landlord, than the provisions of the Conveyancing Act: not only does the scheme of Deasy's Act seem intended to make the position simpler, some questions which arise under the Conveyancing Act, such as whether a covenant has reference to the subject matter

141 See, however, Rainey Brothers Ltd v Kearney [1990] NI 18 (lease forfeited for non-payment of rent by assignee of lessee; lessor held entitled to damages in action against personal representative of assignee for loss sustained following reletting at rent lower than rent payable by assignee): Gumland Property Holdings Pty Ltd v Duffy Bros Fruit Market (Campbelltown) Ltd [2008] HCA 10 (High Court of Australia) (new landlord able to recover loss of bargain damages from lessee).

142 See observations in Lyle v Smith [1909] 2 IR 58 (p. 360 above), and in Liddy v Kennedy (1871) LR 5 HL 134 (p. 367 above).

143 Cf., for leases in England and Wales made after 1995, Landlord and Tenant (Covenants) Act 1995, based on Law Com No. 174, Landlord and Tenant Law: Privity of contract and estate (1988). One of the principles on which the proposals of the Law Commission were based was that "all the terms of the lease should be a single bargain for letting the property. Where the interest of one of the parties changes hands the successor should fully take his predecessor's place as landlord or tenant, without distinguishing between the different categories of covenant." (Law Com No. 174, para 4.1) The Act provides that the benefit and burden of "landlord covenants" and "tenant covenants" pass to successors of the original parties to the tenancy. S. 2(1) provides that the Act applies to a landlord covenant or a tenant covenant "whether or not the covenant has reference to the subject matter of the tenancy". See further Oceanic Village Ltd v United Attractions Ltd [2000] Ch 234; BHP Great Britain Petroleum Ltd v Chesterfield Properties Ltd [2002] Ch 194; London Diocesan Fund Ltd v Phithwa [2005] UKHL 70; Wembley National Stadium Ltd v Wembley (London) Ltd [2007] EWHC 756 (Ch). 
of the lease, or whether a condition is enforceable by a new landlord only if it too has reference to such subject matter, do not arise under Deasy's Act. Conversely, however, for a new landlord who is a lessee of the reversion, the provisions of the later Act may provide the legislative basis for an action against the lessee to enforce covenants, where the applicability to such a case of the provisions of Deasy's Act is unclear.

The last troubling question is whether, given that there are two sets of statutory provisions each of which may be applicable to a dispute between a new landlord and a lessee, it is open to one or other of the parties to select the provision which better suits him or her. To take an example: can a new landlord bring an action for breach of covenant when the breach took place before the new landlord acquired the interest of the original landlord, relying on s. 10 of the Conveyancing Act, or will the lessee be able to point to s. 14 of Deasy's Act as a defence? The more fundamental question, of course, is why the sections of the Conveyancing Act dealing with landlord and tenant matters were made to apply in Ireland, when Deasy's Act had been in force for twenty years already. Were it not that cases exist where different results will follow according to which of the provisions govern the case, the question would not matter. The trouble is that they do, and it does. The provisions of the later statute have received little attention in Ireland because of those of the earlier. If the suggestions in the examination above are correct, it may be necessary for that to change. 